\title{
Work-life balance predicted work ability two years later: a cohort study of employees in the Swedish energy and water sector
}

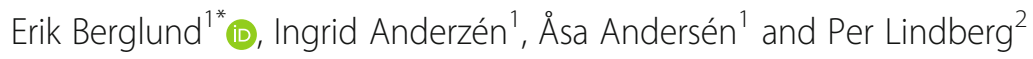

\begin{abstract}
Background: Work-life balance (WLB) is the extent to which individual's multiple life roles and demands carry over between each role. WLB can be divided into work interference with personal life (WIPL) and personal life interference with work (PLIW). This study aimed to investigate longitudinal associations between WIPL, PLIW and work ability outcomes.

Methods: In this cohort study, 224 employees in the energy and water sector in Sweden were followed-up over 2 years. Three questions derived from the Work Ability Index were used for measuring work ability outcome: current work ability compared with lifetime best; work ability regarding physical; and mental demands. Logistic regression models were used to analyse longitudinal associations between work ability and WIPL and WIPL respectively, controlling for workplace (company), position at work, experience of leadership quality, demographics, and work ability.

Results: Work ability compared to lifetime best were associated with WIPL in the adjusted logistic regression models (odds ratio (OR) 1.77, 95\% confidence interval (CI) 1.15-2.73), and PLIW (OR 3.34, 95\% Cl 1.66-6.74). Work ability regarding physical demands was associated with WIPL (OR 1.60, 95\% Cl 1.07-2.40). Work ability regarding mental demands was associated with WIPL (OR 1.59, 95\% Cl 1.03-2.44) and PLIW (OR 2.88, 95\% Cl 1.31-6.32).

Conclusion: In this two-year longitudinal study, lower WIPL predicted good/excellent overall work ability compared with lifetime best, higher work ability regarding physical and mental demands, and lower PLIW predicted good/ excellent overall work ability compared with lifetime best and higher work ability regarding and mental demands.
\end{abstract}

Keywords: Work-life balance, Work ability, Physical demands, Mental demands

\footnotetext{
* Correspondence: erik.berglund@pubcare.uu.se

'Department of Public Health and Caring Sciences, Uppsala University, Box 564, SE-751 22 Uppsala, Sweden

Full list of author information is available at the end of the article
}

(c) The Author(s). 2021 Open Access This article is licensed under a Creative Commons Attribution 4.0 International License, which permits use, sharing, adaptation, distribution and reproduction in any medium or format, as long as you give appropriate credit to the original author(s) and the source, provide a link to the Creative Commons licence, and indicate if changes were made. The images or other third party material in this article are included in the article's Creative Commons licence, unless indicated otherwise in a credit line to the material. If material is not included in the article's Creative Commons licence and your intended use is not permitted by statutory regulation or exceeds the permitted use, you will need to obtain permission directly from the copyright holder. To view a copy of this licence, visit http://creativecommons.org/licenses/by/4.0/. The Creative Commons Public Domain Dedication waiver (http://creativecommons.org/publicdomain/zero/1.0/) applies to the data made available in this article, unless otherwise stated in a credit line to the data. 


\section{Background}

Work ability is generally understood as the capability and capacity to be put into effective operation, among employees work ability concerns how well a worker is able to perform his or her work [1-3]. Even if there is no uniform definition of work ability in the literature [4]; work ability often includes physical, mental and social resources [5]. The concept of work ability may be divided into general and specific work ability [6]. Having work ability in a general sense is having the health, standard basic competence and the basic occupational virtues required for perform some kind of job, assuming that the work tasks are reasonable and that the work environment is acceptable. Having work ability in a specific sense, is having (some set of) the required manual, intellectual and social competence together with health and the relevant job-specific virtues that are required for managing the specific work tasks. Work ability has been shown to have predictive value for several outcomes, including; productivity [7], sick leave/absence [8, 9], job survival [10], work-related disability [11], and mortality [12].

Several factors have been proposed to influence employee's work ability [5], e.g. individual factors, such as physical, psychological and cognitive functioning $[13,14]$. There are also environmental factors of importance, which can be found both in the physical and social environment, and within or without the individuals' workplace [13, 15]. Leadership constitute one dimension, "leadership climate", of the psychosocial work environment that could have a prospective relationship with work ability $[16,17]$. In the occupational health literature, the concept of work ability is often considered to be depending on the balance between personal resources and work demands [5], and models such as the Job Demands-Resources [18], and the Spillover model [19], are often applied. Factors outside the workplace has gained in interest, and especially the intersection between work life and private life [20], and scholars have produced a substantial body of theoretical literature on the linking of work and private life [20, 21]. Work-life balance (WLB) is a broad concept and much similar to the concept of workfamily balance.

The concept of WLB is often drawn from individual's multiple life roles and from the recognition that nonwork demands may carry over into the work, and adversely influence the individual in several ways. Several different definitions have been proposed [22, 23]. A quite ordinary understanding is that WBL reflects an individual's orientation across different life roles, and is an inter-role phenomenon [23-25]. Especially one theory in the occupational stress literature has particular relevance for guiding research on WLB, namely role theory [26].
Role theory is based on the premise that an individual's life is comprised of several roles and the responsibilities that follow each role, including roles at work, as well as roles outside of work [27]. WLB can be fractionated into how much one role in life interferes with another role, such as if work interferes with personal life or vice versa. The theory states that there is a risk for a role conflict, or imbalance, to occur if pressures occur at the same time in two (or more) sets, especially if compliance with one set makes it more difficult to comply with the other set. Empirical research supports that work-life imbalance is associated with worse work related outcomes [28], and vice versa, a good WLB are considered to increase outcomes such as productivity [29], job and life satisfaction [30].

A workforce with long-term sustainable work ability is important to promote, not least because of the ageing population [31, 32]. Younger adults who are entering the work force today are expected to have a longer working life than preceding generation and therefore needs to maintain a sufficient work ability over a longer time frame $[33,34]$. The work ability can be affected by a number of different factors and there is still a lack of a knowledge in the field; a not fully explored and interesting consideration is how WLB predicts work ability. The aim of this study was to investigate if lower interferes between work and private life predicted higher selfassessed work ability among white and blue collar workers in the energy and water sector in Sweden.

\section{Methods}

\section{Setting and study population}

This is a two-year longitudinal, questionnaire based study performed in three companies in the energy and water sector in Sweden. The present study is a part of an evaluation of the GodA-project (Swedish abbreviation for "Good work environment and healthy workplace") [35]. GodA was inspired by the Practices for the Achievement of Total Health (PATH) model [36], and the intention was to carry out a PATH-based intervention aimed at enhancing internal communication in one of the companies (company 3), but the intervention was however not implemented to full extent due to organizational changes in the company at the time. In the present study, all employees in both the intervention and the control companies were treated as one cohort within a longitudinal study design, however the analyses were adjusted for company. The inclusion criteria were being permanently employed and in service in one of these companies at the time for the data collection. Both white and blue collar workers were included, as well as employees on short-term and/or part-time sick-leave and those who were home caring for a sick child. Employees on long-term sick-leave, parental leave or on a 
leave of absence were excluded. The questionnaires were distributed by e-mail, but there was also a paper-and-pencil questionnaire option for a few employees who did not feel comfortable using a computer. The baseline questionnaire, Time $0\left(\mathrm{~T}_{0}\right)$, was distributed in 2013 to all 408 employees in the three companies. A total of 302 employees answered the $\mathrm{T}_{0}$ questionnaire making a response rate of $74 \%$. The follow-up questionnaire, Time $1\left(T_{1}\right)$, was disturbed in 2015 to all employed and in service at the time, 422 employees, of which 319 answered the questionnaire making a response rate of $76 \%$. A total of 224 employees answered both the baseline and the follow-up questionnaires (55\% of the initially asked) and form the study population in this study. See the flow-chart in Fig. 1. In addition, demographic data and information about work position were obtained from administration registers of the three participating companies.

\section{Explanatory measures}

Data gathered in 2013 related to demographics, employment and WLB were used as explanatory measures in this study.

\section{Demographics}

Information about gender and age were obtained from the administration registers of the three participating companies. Educational level (categorized as compulsory school, secondary school or university) was collected through the questionnaires.

\section{Employment}

Data of employment was obtained from the administration registers of the three participating companies, which company the employees had their contracts, and which position the employees hold (categorized as production, administration and management position). Experienced leadership quality in the workplace was based on an index with seven indicators that was developed for this study. The following statements were used for measuring leadership quality: "Our managers treat us employees in a fair way", "Our managers are hopeful even at setbacks", "The information from the managers is clear to me", "My immediate superior is easy to reach", "My immediate superior is committed to what I do", "My immediate superior is responsive if I have ideas and opinions", and "My immediate superior contributes when problems needs to be quickly solved". Answers were collected with

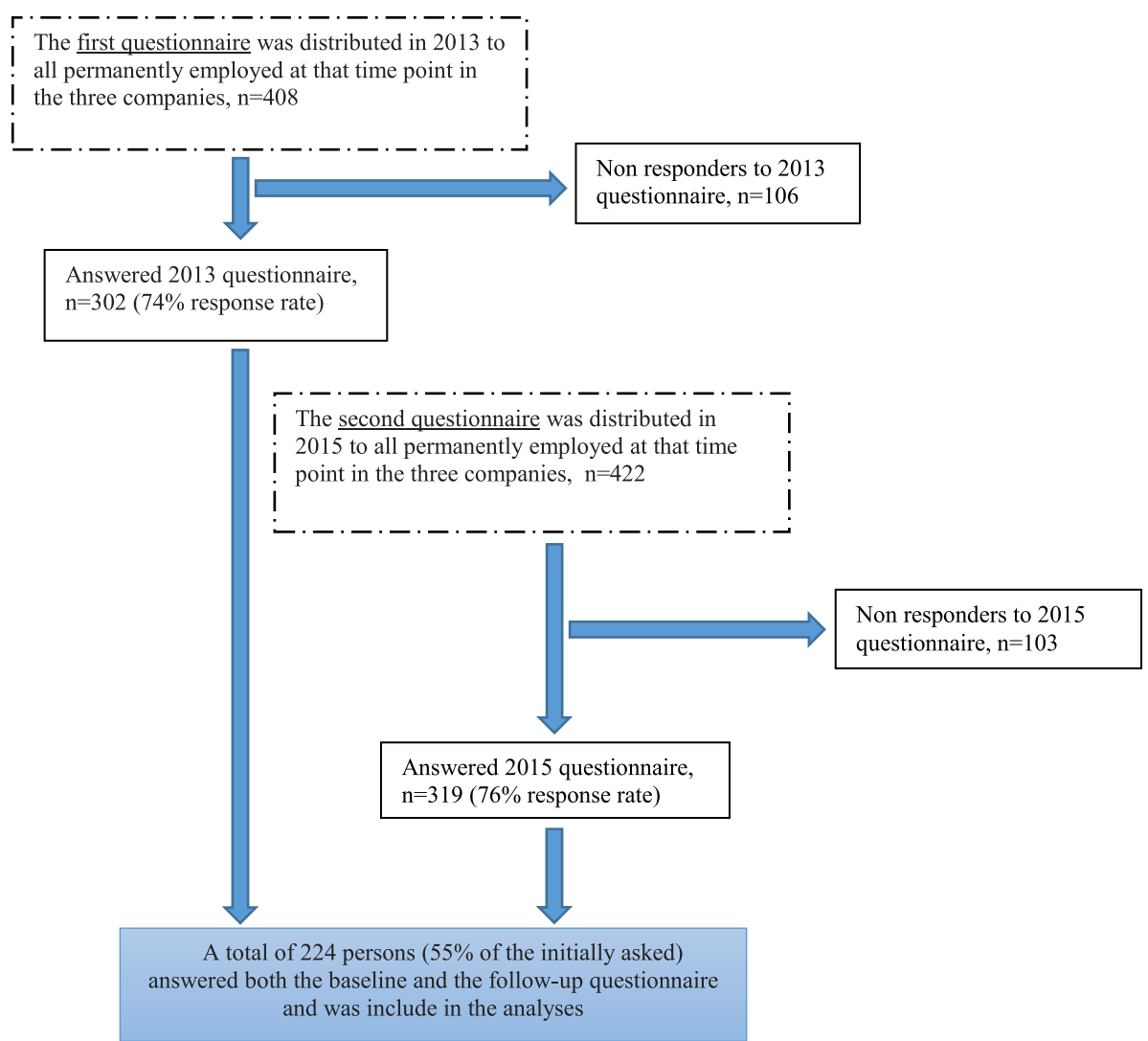

Fig. 1 Flow-chart of the study population and the data collection process 
the following alternatives: 1 . Not at all; 2. To a small extent; 3. Partially; 4. Highly; 5. Very much; and 6. Extremely high. Experience of leadership quality were calculated into an index ranging from 1 to 6 , were a higher score indicated better experience of leadership quality.

\section{WLB}

In research, the concept of WLB can be measured in several ways [22, 37, 38]. In this study, the measure for WLB was based on six items from the Fisher, Bulger and Smith's WLB scale from 2009 [39]. The original scale assesses four dimensions: work interference with personal life (WIPL) and personal life interference with work (PLIW), work enhancement of personal life, and personal life enhancement of work. In this study, three questions were based of the WIPL dimension, and three items were based of the PLIW dimension. Both WIPL and PLIW were measured as how much each of these two dimensions affect (or interfere) on the other dimension. WIPL was assessed with answers to the following three statements: "When I come home from work I am too tired to do the things I would have liked to do", "My private life doesn't look the way I would like it to be because of my work", and "I often overlook personal needs because of demands in my work". PLIW was assessed with answers to the following three statements: "My work suffers from what's happening in my private life", "I would like to devote more time to work if it wasn't for everything that happens in private life", and "I'm too tired to be effective at work because of everything that happens in my private life". Answers regarding WIPL and PLIW were collected with the following alternatives: 1. Almost all the time; 2. Often; 3. Sometimes; 4 . Rarely; and 5. Not at all. WIPL and PLIW were both calculated into indices, ranging from 1 to 5 . Higher scores indicated a lower interference and were interpreted as a more advantageous work-life balance, this direction of coding the answers has previously been used for the measure [40]. The WIPL and PLIW were used as separate factors in the analyses.

\section{Outcome measures}

The outcome, self-assessed work ability, was measured at baseline and at follow-up. The first three questions, out of the original seven, from the Work Ability Index (WAI) were used in this study [41]. It is common to use parts of the WAI and not all questions due to space considerations in the questionnaire and high correlations among the indicators and the total score [42, 43]. The first question in WAI is known as the Work Ability Score (WAS) and asses current work ability compared with lifetime best [44], the question is outlined: "Assume that your work ability at its best has a value of 10 points.
How many points would you give your current work ability?" This question is scored from 0 to 10 . In this study, a cut-off score of 7 was used to dichotomized WAS into: Poor/moderate work ability (score $0-7$ ) and good/excellent work ability (score 8-10) compared to lifetime best, for the binary logistic regression analyses. The cut-off score was chosen due to previous research which often classify a score of $0-7$ points as poor and moderate, and 8-10 points as good and excellent work ability in WAS $[45,46]$. The second WAI question concerned work ability regarding physical demands: "How do you rate your current work ability with respect to the physical demands of your work?" The third WAI question concerned work ability regarding mental demands: "How do you rate your current work ability with respect to the mental demands of your work?" The second and third WAI questions were assigned with five response options: 1. Very poor; 2. Rather poor; 3 . Neither good nor poor; 4. Rather good; and 5.Very good. In this study, the work ability concerning physical and mental demands was dichotomized with a cut-off score of 4: into lower work ability $(=0)$ and higher work ability $(=1)$, for the binary logistic regression analyses. The three dimensions of WAI were analyzed separately.

\section{Statistical analysis}

The data were analyzed using Chi-square tests to compare differences in percentage distributions and ANOVA for test differences between mean values. Spearman's rho was used to explore the bivariate relationships between variables and used to summarize the data. Binary logistic regression analyses were used to study the longitudinal associations between the predictors at $\mathrm{T}_{0}$ and the outcomes at $T_{1}$. A stepwise approach was performed for the logistic multiple regression models using sets of independent variables. Model 1 included PLIW and WIPL at $\mathrm{T}_{0}$. Model 2 included Model 1, company, position at work and experience of leadership quality at $\mathrm{T}_{0}$. Model $3 \mathrm{in}$ cluded Model 2 and demographics at $\mathrm{T}_{0}$. Model 4 included Model 3 and the baseline work ability measure as was used as outcome in the current analysis. When work ability compared with lifetime best at $\mathrm{T}_{1}$ was the dependent variable, work ability compared with lifetime best at $\mathrm{T}_{0}$ was controlled for, and when work ability regarding physical demands at $\mathrm{T}_{1}$ was the dependent variable, work ability regarding physical demands at $T_{0}$ was controlled for, and so on. Adjusting for baseline work ability reduces the risk for "reverse" effects as a plausible explanation for relationships between predictors and outcomes [16]. All tests were two-sided, and a $p$ value $\leq 0.05$ was considered statistically significant. Statistical Package for the Social Sciences (SPSS) ${ }^{\circ}$ version 25 (IBM SPSS Statistics for Windows, Armonk, NY: IBM Corp Chicago, IL, U.S.A.) was used for all statistical analyses. 


\section{Results}

The study population consisted of $73 \%$ men and $27 \%$ women and the average age of the study population was 47 years. Secondary or equivalent school was the most common completed education level. Among the study participants, $32 \%$ worked in production, $50 \%$ in administration, and $18 \%$ had a management position. The distribution of demographics in the study population are shown in Table 1.

\section{Work-life balance}

On average WIPL score was $3.7(\mathrm{SD}=0.9)$ and PLIW score was $4.6(\mathrm{SD}=0.5)$, in the total study population at baseline. No statistically significant differences were found between the three company's employees regarding WIPL and PLIW, see Table 1.

\section{Work ability among the employees}

In the total study sample, a majority of the employees (75\%) reported good/excellent work ability compared to lifetime best, and $25 \%$ reported a poor/moderate work ability compared to lifetime best, at follow-up. When the 4-point cut-off of was used 59\% reported a higher work ability regarding physical demands and $41 \%$ reported a higher work ability regarding mental demands at follow-up, see Table 2. There were no statistically significant differences between those workers who answered at baseline but not at followup and those who responded to both questionnaires regarding baseline WAS, work ability regarding physical and mental demands.

\section{Correlation matrix and logistic regressions}

WIPL and PLIW both correlated with work ability compared to lifetime best and work ability regarding physical, as well as, mental demands, see Table 3.

Work ability compared to lifetime best at follow-up, WIPL, PLIW, company, position at work, experience of leadership quality, demographics and baseline work ability compared to lifetime best were analyzed using binary logistic regression, see Table 4 . There was a statistically significant association between WIPL and good/excellent work ability compared to lifetime best, in the adjusted logistic regression models (odds ratio (OR) 1.77, 95\% confidence interval (CI) 1.15-2.73). There was also a statistical significant association between PLIW and good/excellent work ability compared to lifetime best (adjusted OR 3.34, 95\% CI 1.66-6.74).

Work ability regarding physical demands at follow-up, WIPL, PLIW, company, position at work, experience of leadership quality, demographics and baseline work ability regarding physical demands were analyzed using binary logistic regression, see Table 5. There was a statistically significant association between WIPL and higher work ability regarding physical demands (adjusted OR 1.60, 95\% CI 1.07-2.40). There was also a statistically significant association between experience of leadership quality and higher work ability regarding physical demands (adjusted OR 1.51, 95\% CI 1.02-2.22).

Work ability regarding mental demands at follow-up, WIPL, PLIW, company, position at work, experience of leadership quality, demographics and baseline work ability mental demands were analyzed using binary logistic

Table 1 Baseline demographics and characteristics of the study population, distributed by company

\begin{tabular}{|c|c|c|c|c|c|}
\hline & & $\begin{array}{l}\text { Company } 1 \\
n=30(13.4)\end{array}$ & $\begin{array}{l}\text { Company } 2 \\
n=108(48.2)\end{array}$ & $\begin{array}{l}\text { Company } 3 \\
n=86(38.4)\end{array}$ & $\begin{array}{l}\text { Total } \\
n=224(100)\end{array}$ \\
\hline \multirow[t]{2}{*}{ Sex, n (\%) } & Male & $20(66.7)$ & $81(75.0)$ & $63(73.3)$ & 164 (73.2) \\
\hline & Female & $10(33.3)$ & $27(25.0)$ & $23(26.7)$ & $60(26.8)$ \\
\hline Age & Md, Mean $( \pm S D)$ & $48,47.1(10.4)$ & $47,47.3(9.2)$ & $48,46.6(10.0)$ & $48,47.0(9.6)$ \\
\hline \multirow[t]{3}{*}{ Education, n (\%) } & Primary school & $8(26.7)^{*}$ & $11(10.2)^{*}$ & $22(25.6)^{*}$ & $41(18.3)$ \\
\hline & Secondary school or equal & $10(33.3)^{*}$ & $67(62.0)^{*}$ & $43(50.0)^{*}$ & $120(53.6)$ \\
\hline & University & $12(40.0)^{*}$ & $30(27.8)^{*}$ & $21(24.4)^{*}$ & $63(28.1)$ \\
\hline \multirow[t]{3}{*}{ Position at work, n (\%) } & Production & $9(31)$ & $29(26.9)$ & $34(39.5)$ & $72(32.4)$ \\
\hline & Administration & $14(48.3)$ & $62(57.4)$ & $35(40.7)$ & $111(49.8)$ \\
\hline & Manager & $6(20.7)$ & $17(15.7)$ & $17(19.8)$ & $40(17.9)$ \\
\hline Experience of leadership quality ${ }^{a}$ & Md, Mean ( $\pm S D)$ & $4.0,4.0(0.8)$ & $4.0,3.9(0.9)$ & $4.0,3.9(0.9)$ & $4.0,3.9(0.9)$ \\
\hline \multirow[t]{2}{*}{ Work-life balance } & WIPL, Mean $( \pm S D)^{b}$ & $3.49(1.1)$ & $3.79(0.9)$ & $3.76(0.9)$ & $3.74(0.9)$ \\
\hline & PLIW, Mean $( \pm S D)^{b}$ & $4.67(0.5)$ & $4.58(0.5)$ & $4.58(0.6)$ & $4.59(0.5)$ \\
\hline
\end{tabular}

Figures as number (n) or percentages if not stated otherwise. Pearson Chi-Square test was used for distributions and ANOVA test was used for mean ${ }^{a}$ Experience with leadership quality was measured with an index, ranging from 1 to 6 . Higher score indicates better experience with management ${ }^{b}$ Work interference with personal life (WIPL) and personal life interference with work (PLIW), was both three item index scales, ranging from 1 to 5 ${ }^{*} P \leq 0.05$ 
Table 2 Work ability measures at baseline and follow-up

\begin{tabular}{|c|c|c|c|}
\hline & & Baseline $\left(T_{0}\right)$ & Follow-up $\left(T_{1}\right)$ \\
\hline \multirow[t]{3}{*}{ Work ability compared to lifetime best } & Md, Mean $( \pm S D)^{a}$ & $7.0,6.5(1.4)$ & $9.0,8.3(1.5)$ \\
\hline & Poor/moderate work ability compared to lifetime best ${ }^{b}$ & 73.7 & 25.1 \\
\hline & Good/excellent work ability compared to lifetime best ${ }^{b}$ & 26.3 & 74.9 \\
\hline \multirow[t]{3}{*}{ Work ability regarding physical demands } & Md, Mean $( \pm S D)^{c}$ & $5.0,4.4(0.7)$ & $5.0,4.5(0.6)$ \\
\hline & Lower work ability regarding physical demands ${ }^{d}$ & 46.0 & 41.3 \\
\hline & Higher work ability regarding physical demands ${ }^{d}$ & 54.0 & 58.7 \\
\hline \multirow[t]{3}{*}{ Work ability regarding mental demands } & $\mathrm{Md}$, Mean $( \pm \mathrm{SD})^{\mathrm{c}}$ & 4.0, $4.2(0.8)$ & 4.0, $4.2(0.8)$ \\
\hline & Lower work ability regarding mental demands ${ }^{\mathrm{d}}$ & 65.6 & 59.2 \\
\hline & Higher work ability regarding mental demands ${ }^{d}$ & 34.4 & 40.8 \\
\hline
\end{tabular}

Figures are percentage if not stated otherwise

aWork ability compared with lifetime best was ranging from 0 (= worse) to 10 (= best)

${ }^{b}$ Work ability compared with lifetime best was dichotomized into: Poor/moderate work ability compared to lifetime best (=0) and good/excellent work ability compared to lifetime best $(=1)$

'Work ability regarding physical and mental demands was ranging from 0 (= worse) and 5 (= best)

${ }^{\mathrm{d}}$ Work ability regarding physical and mental demands was dichotomized into: lower work ability $(=0)$ and higher work ability $(=1)$

regression, see Table 6 . There were statistically significant associations between, WIPL as well as PLIW, and higher work ability regarding mental demands, with adjusted OR 1.59, 95\% CI 1.03-2.44, and adjusted OR 2.88, 95\% CI 1.31-6.32, respectively.

\section{Discussion}

This study investigated longitudinal associations of WIPL, PLIW and work ability outcomes 2 years later among employees in the Swedish energy and water sector. This study found that WIPL predicted work ability

Table 3 Correlation matrix among variables

\begin{tabular}{|c|c|c|c|c|c|c|c|c|c|c|c|c|c|c|}
\hline & Min - max & 1 & 2 & 3 & 4 & 5 & 6 & 7 & 8 & 9 & 10 & 11 & 12 & 13 \\
\hline 1. Sex & $1-2$ & & & & & & & & & & & & & \\
\hline 2. Age & $21-64$ &,- 09 & & & & & & & & & & & & \\
\hline 3. Education level & $1-3$ & $.26^{* *}$ & $-.25^{* *}$ & & & & & & & & & & & \\
\hline 4. Company & $1-3$ & -.02 & -.02 & -.11 & & & & & & & & & & \\
\hline 5. Position at work & $1-3$ & $.14^{*}$ & -.01 & $.38^{* *}$ & -.07 & & & & & & & & & \\
\hline 6. Experience with leadership quality ${ }^{a}$ & $1-6$ & .06 & .04 & .07 & .03 & $.19^{* *}$ & & & & & & & & \\
\hline 7. WIPL ${ }^{b}$ & $1-5$ & $-.20^{* *}$ & .07 & $-.27^{* *}$ & .04 & $-.24^{* *}$ & -.02 & & & & & & & \\
\hline 8. PLIN & $1-5$ & .00 & $.14^{*}$ & $-.23^{* *}$ & -.024 & -.11 & -.02 & $.39^{* *}$ & & & & & & \\
\hline $\begin{array}{l}\text { 9. Work ability compared with the lifetime } \\
\text { best at } T_{0}\end{array}$ & $0-10$ & -.03 & -.10 & -.10 & $-.14^{*}$ & -.08 & .06 & $.38^{* *}$ & $.40^{* *}$ & & & & & \\
\hline $\begin{array}{l}\text { 10. Work ability regarding physical demands } \\
\text { at } T_{0}\end{array}$ & $1-5$ & $-.13^{*}$ & -.07 & .10 & .10 & $.14^{*}$ & $.19^{* *}$ & $.24^{* *}$ & $.14^{*}$ & $.46^{* *}$ & & & & \\
\hline $\begin{array}{l}\text { 11. Work ability regarding mental demands } \\
\text { at } T_{0}\end{array}$ & $1-5$ & -.09 & -.05 & -.06 & .046 & -.06 & $.20^{* *}$ & $.36^{* *}$ & $.27^{* *}$ & $.68^{* *}$ & $.59 * *$ & & & \\
\hline $\begin{array}{l}\text { 12. Work ability compared with the lifetime } \\
\text { best at } T_{1}\end{array}$ & $0-10$ & -.02 & -.07 & -.02 & .03 & .02 & .09 & $.34^{* *}$ & $.37^{* *}$ & $.56^{* *}$ & $.38^{* *}$ & $.48^{* *}$ & & \\
\hline $\begin{array}{l}\text { 13. Work ability regarding physical demands } \\
\text { at } T_{1}\end{array}$ & $1-5$ & .08 & -.09 & $.17^{*}$ & .03 & $.16^{*}$ & $.22^{* *}$ & $.22^{* *}$ & $.17^{*}$ & $.33^{* *}$ & $.44^{* *}$ & $.36^{* *}$ & $.53^{* *}$ & \\
\hline $\begin{array}{l}\text { 14. Work ability regarding mental demands } \\
\text { at } T_{1}\end{array}$ & $1-5$ & -.10 & -.01 & .03 & -.05 & -.02 & $.14^{*}$ & $.36^{* *}$ & $.28^{* *}$ & $.45^{* *}$ & $.32^{* *}$ & $.46^{* *}$ & $.65^{* *}$ & $.56^{* *}$ \\
\hline
\end{tabular}

The matrix has been calculated with Spearman's correlation coefficient

Maximum (max), minimum ( $\mathrm{min}$ ) of the scale or index, and correlations indicated

${ }^{\mathrm{a}}$ Experience with leadership quality was measured with an 7 item index ranging from 1 to 6

${ }^{b}$ Work interference with personal life (WIPL) and personal life interference with work (PLIW), was both three item index scales, ranging from 1 to 5

'Work ability outcome in the matrix was measured at follow-up

* Correlation is significant at the 0.05 level

** Correlation is significant at the 0.01 level 
Table 4 Results of logistic regression models of factors predicting good/excellent work ability compared with the lifetime best

\begin{tabular}{|c|c|c|c|c|c|c|}
\hline & & $\begin{array}{l}\text { Crude } \\
\text { OR 95\% Cl }\end{array}$ & $\begin{array}{l}\text { Model } 1 \\
\text { OR } 95 \% \mathrm{Cl}\end{array}$ & $\begin{array}{l}\text { Model } 2 \\
\text { OR 95\% Cl }\end{array}$ & $\begin{array}{l}\text { Model } 3 \\
\text { OR 95\% Cl }\end{array}$ & $\begin{array}{l}\text { Model } 4 \\
\text { OR } 95 \% \mathrm{Cl}\end{array}$ \\
\hline \multirow[t]{2}{*}{ Work-life balance } & $\mathrm{WIPL}^{a}$ & $2.12^{* *}$ (1.49 to 2.98$)$ & $1.72^{* *}$ (1.18 to 2.49 ) & $1.90^{* *}$ (1.27 to 2.84 ) & $1.93^{* *}$ (1.26 to 2.94 ) & $1.77^{* *}$ (1.15 to 2.73 ) \\
\hline & PLIW $^{a}$ & $4.67^{* *}$ (2.59 to 8.43 ) & $3.70^{* *}$ (2.01 to 6.80 ) & $3.82^{* *}$ (2.01 to 7.26$)$ & $4.13^{* *}$ (2.08 to 8.21 ) & $3.34^{* *}$ (1.66 to 6.74 ) \\
\hline \multirow[t]{9}{*}{ Employment } & Company & & & & & \\
\hline & Company 1 & 1 & & 1 & 1 & 1 \\
\hline & Company 2 & 1.18 (0.45 to 3.09$)$ & & 1.39 (0.46 to 4.25$)$ & 1.65 (0.52 to 5.25$)$ & 1.87 (0.58 to 6.08) \\
\hline & Company 3 & 0.67 (0.25 to 1.74$)$ & & $0.60(0.20$ to 1.81$)$ & 0.61 (0.20 to 1.88$)$ & 0.65 (0.21 to 2.07$)$ \\
\hline & Position at work & & & & & \\
\hline & Production & 1 & & 1 & 1 & 1 \\
\hline & Administration & 1.23 (0.68 to 2.22 ) & & 1.04 (0.46 to 2.36$)$ & 1.10 (0.45 to 2.67$)$ & 1.12 (0.46 to 2.73 ) \\
\hline & Manager & 1.77 (0.81 to 3.88$)$ & & 2.85 (0.90 to 9.03$)$ & 3.41 (0.99 to 11.70 ) & $3.55^{*}(1.02$ to 12.36$)$ \\
\hline & $\begin{array}{l}\text { Experience of } \\
\text { leadership quality }\end{array}$ & 1.37 (0.96 to 1.94$)$ & & 1.45 (0.95 to 2.23$)$ & 1.45 (0.94 to 2.23$)$ & 1.48 (0.94 to 2.35$)$ \\
\hline \multirow[t]{8}{*}{ Demographic } & Gender & & & & & \\
\hline & Male & 1 & & & 1 & 1 \\
\hline & Female & 0.81 (0.47 to 1.42 ) & & & 0.97 (0.41 to 2.30$)$ & 1.01 (0.42 to 2.42$)$ \\
\hline & Age & 0.96 (0.96 to 1.03$)$ & & & $0.97(0.94$ to 1.01$)$ & 0.98 (0.94 to 1.02$)$ \\
\hline & Education level & & & & & \\
\hline & University & 1 & & & 1 & 1 \\
\hline & $\begin{array}{l}\text { Secondary school } \\
\text { or equal }\end{array}$ & 0.64 (0.29 to 1.43$)$ & & & 0.48 (0.16 to 1.43$)$ & $0.43(0.14$ to 1.33$)$ \\
\hline & Compulsory school & $0.55(0.24$ to 1.28$)$ & & & $0.56(0.15$ to 1.20$)$ & 0.48 (0.13 to 1.79$)$ \\
\hline \multirow{2}{*}{$\begin{array}{l}\text { Baseline work ability } \\
\text { regarding work ability } \\
\text { compared with the } \\
\text { lifetime best }\end{array}$} & Poor/moderate at $\mathrm{T}_{0}$ & 1 & & & & 1 \\
\hline & Good/excellent at $\mathrm{T}_{0}$ & $8.91^{* *}$ (2.67 to 29.79 ) & & & & $4.63^{*}(1.28$ to 16.76$)$ \\
\hline Nagelkerke R Square $\left(R^{2}\right)$ & & & $24 \%$ & $31 \%$ & $32 \%$ & $36 \%$ \\
\hline$\Delta \mathrm{R}^{2}$ & & & & $7 \%$ & $1 \%$ & $4 \%$ \\
\hline
\end{tabular}

Odds ratio (OR), $95 \% \mathrm{Cl}$ : 95\% confidence interval of factors predicting good/excellent work ability compared with the lifetime best. Work ability compared with the lifetime best was dichotomized into: Poor/moderate work ability compared to lifetime best (=0) and good/excellent work ability compared to lifetime best $(=1) .{ }^{*} P \leq 0.05,{ }^{* *} P \leq 0.01{ }^{\text {a }}$ Work interference with personal life (WIPL) and personal life interference with work (PLIW), was both three item index scales, ranging from 1 to $5{ }^{\text {b }}$ Experience with leadership quality was measured with an index, ranging from 1 to 6 . Model $1=$ PLIW+WIPL, Model 2 = Model 1 + company+position at work+experience of leadership quality, Model $3=$ Model $2+$ gender+age + education level, Model 4 = Model $3+$ baseline work ability compared with the lifetime best

compared to lifetime best as well as work ability regarding physical and mental demands. PLIW predicted work ability compared to lifetime best and work ability regarding mental demands.

WLB is experienced when demands from work are compatible with demands from other domains in life, e.g. family or leisure time, and a 'balanced' situation occurs when demands from one domain do not negatively affect activities in the other domains [38]. In this study, WLB was divided into two separate factors or dimensions, 'work interference with personal life' and 'personal life interference with work', and used as separate predictors. The main reason for this strategy was to explore what kind of "role-related" balance, work or private, in a person's life that could have specific importance for the various work ability outcomes. The analyses showed that work ability regarding physical demands was influenced by WIPL, and work ability regarding mental demands was influenced by WIPL as well as by PLIW. The explanations behind these results needs further attention in the research. Possibly, physical work ability is more solely dependent on work conditions in general, while mental work ability is also sensitive for conditions outside the workplace and a person's close community. Another, possible explanation for the results, is that the explanation might lie more in different types of jobs (and associated demands). To uphold a job that, to the largest part, have high physical requirements might be less dependent on the home conditions than on conditions at work. On the other side, a job that have high mental requirements seems to be conditioned also on home circumstances, possibly because thoughts and 
Table 5 Results of logistic regression models of factors predicting higher work ability regarding physical demands

\begin{tabular}{|c|c|c|c|c|c|c|}
\hline & & $\begin{array}{l}\text { Crude } \\
\text { OR } 95 \% \mathrm{Cl}\end{array}$ & $\begin{array}{l}\text { Model } 1 \\
\text { OR } 95 \% \mathrm{Cl}\end{array}$ & $\begin{array}{l}\text { Model } 2 \\
\text { OR } 95 \% \mathrm{Cl}\end{array}$ & $\begin{array}{l}\text { Model } 3 \\
\text { OR } 95 \% \mathrm{Cl}\end{array}$ & $\begin{array}{l}\text { Model } 4 \\
\text { OR 95\% Cl }\end{array}$ \\
\hline \multirow[t]{2}{*}{ Work-life balance } & WIPL ${ }^{a}$ & $1.49^{* *}(1.10$ to 2.00$)$ & $1.41^{*}$ (1.03 to 1.93$)$ & $1.62^{* *}$ (1.15 to 2.30$)$ & $1.84^{* *}$ (1.27 to 2.69$)$ & $1.60^{*}(1.07$ to 2.40$)$ \\
\hline & PLIW $^{\mathrm{a}}$ & 1.61 (0.98 to 2.65$)$ & 1.33 (0.78 to 2.26$)$ & 1.39 (0.79 to 2.45$)$ & 1.60 (0.86 to 2.98$)$ & 1.41 (0.72 to 2.76$)$ \\
\hline \multirow[t]{9}{*}{ Employment } & Company & & & & & \\
\hline & Company 1 & 1 & & 1 & 1 & 1 \\
\hline & Company 2 & 1.81 (0.99 to 3.30) & & 1.54 (0.64 to 3.72 ) & 1.81 (0.72 to 4.57$)$ & 1.52 (0.55 to 4.17$)$ \\
\hline & Company 3 & $2.61^{*}(1.15$ to 5.92$)$ & & 1.70 (0.69 to 4.20$)$ & 2.00 (0.78 to 5.12$)$ & 1.42 (0.51 to 3.98$)$ \\
\hline & Position at work & & & & & \\
\hline & Production & 1 & & 1 & 1 & 1 \\
\hline & Administration & 0.77 (0.40 to 1.47$)$ & & $2.28^{*}(1.17$ to 4.46$)$ & 1.61 (0.77 to 3.39$)$ & 1.55 (0.69 to 3.49$)$ \\
\hline & Manager & 1.15 (0.48 to 2.79 ) & & $3.31^{* *}$ (1.33 to 8.26$)$ & 2.49 (0.94 to 6.59$)$ & 1.91 (0.67 to 5.40$)$ \\
\hline & $\begin{array}{l}\text { Experience of } \\
\text { leadership quality }\end{array}$ & $1.68^{* *}$ (1.21 to 2.33$)$ & & $1.59^{* *}(1.12$ to 2.27$)$ & $1.62^{* *}$ (1.13 to 2.33 ) & $1.51^{*}(1.02$ to 2.22$)$ \\
\hline \multirow[t]{8}{*}{ Demographic } & Gender & & & & & \\
\hline & Male & 1 & & & 1 & 1 \\
\hline & Female & 1.53 (0.92 to 2.56$)$ & & & 1.36 (0.64 to 2.89$)$ & 1.95 (0.85 to 4.49$)$ \\
\hline & Age & 0.99 (0.96 to 1.01$)$ & & & 0.98 (0.95 to 1.02$)$ & 0.99 (0.95 to 1.02 ) \\
\hline & Education level & & & & & \\
\hline & University & 1 & & & 1 & 1 \\
\hline & $\begin{array}{l}\text { Secondary school } \\
\text { or equal }\end{array}$ & 1.40 (0.76 to 2.58$)$ & & & 0.98 (0.42 to 2.30$)$ & 0.96 (0.38 to 2.44$)$ \\
\hline & Compulsory school & $3.49^{* *}(1.72$ to 7.08$)$ & & & 2.75 (0.92 to 8.25$)$ & 2.06 (0.63 to 6.76$)$ \\
\hline \multirow{2}{*}{$\begin{array}{l}\text { Baseline work ability } \\
\text { regarding physical } \\
\text { demands }\end{array}$} & Lower at $\mathrm{T}_{0}$ & 1 & & & & 1 \\
\hline & Higher at $T_{0}$ & $6.70^{* *}$ (3.70 to 12.14 ) & & & & $5.43^{* *}$ (2.78 to 10.62$)$ \\
\hline \multicolumn{2}{|l|}{ Nagelkerke $R$ Square $\left(R^{2}\right)$} & & $5 \%$ & $17 \%$ & $22 \%$ & $35 \%$ \\
\hline \multicolumn{2}{|l|}{$\Delta R^{2}$} & & & $12 \%$ & $5 \%$ & $13 \%$ \\
\hline
\end{tabular}

Odds ratio (OR), 95\% Cl: 95\% confidence interval of factors predicting higher work ability regarding physical demands. Work ability regarding physical demands was dichotomized into lower work ability $(=0)$ and higher work ability $(=1){ }^{*} P \leq 0.05,{ }^{* *} P \leq 0.01$ a Work interference with personal life (WIPL) and personal life interference with work (PLIW), was both three item index scales, ranging from 1 to $5 .{ }^{b}$ Experience with leadership quality was measured with an index, ranging from 1 to 6 . Model $1=$ WIPL+PLIW, Model $2=$ Model $1+$ company+position at work+experience of leadership quality, Model 3 = Model $2+$ gender+age + education level, Model $4=$ Model $3+$ baseline work ability regarding physical demands

feelings do not stop influencing the employee's mental state at the moment he or she leaves the home and enters the workplace.

The concept of WLB has gained in attention, and involved both governments, political institutions, companies employers and employees' organizations in the discussions [38]. The concept of WLB has largely generated from role theory and the increasing interest in 'work-life conflict' as a topic of academic and practitioner debate [26, 47]. Work-life conflicts engenders thru the loss of resources (e.g. time) and the multiple roles that individuals occupy and the competing demands between work and home [48]. Work-life conflicts are also assumed to have increased in relevance for employees in recent years due to changes in demography, workplace, working hours, and communication technology enabling a closer contact with the workplace [47]. This has raised the interest for organizations to implement WLB policies and practices (a.k.a. organizational family-supportive or family-friendly policy's). WLB practices usually refers to practices that includes support for dependent care, flexible work options, family or personal leave, flexible work hours (e.g., flextime, compressed work week, etc.), home-based work, job sharing, onsite childcare or assistance with childcare and eldercare services [47]. However, the purpose for implementing such practices may not always be to reduce work-life conflicts exclusively, other reason might e.g. be by offering these practices; organizations want to attract new employees as well as to retain existing ones $[47,49]$. In the long run WLB practices often wishes to accomplish goals regarding increased organizational effectiveness and performance, which also have some empirical support $[29,49,50]$.

The results of this study support the assumption that long-term work ability are impacted of WLB, and suggests that an approach managing WLB might influence work ability over time. Such interventions may be 
Table 6 Results of logistic regression models of factors predicting higher work ability regarding mental demands

\begin{tabular}{|c|c|c|c|c|c|c|}
\hline & & $\begin{array}{l}\text { Crude } \\
\text { OR } 95 \% \mathrm{Cl}\end{array}$ & $\begin{array}{l}\text { Model } 1 \\
\text { OR } 95 \% \mathrm{Cl}\end{array}$ & $\begin{array}{l}\text { Model } 2 \\
\text { OR } 95 \% \mathrm{Cl}\end{array}$ & $\begin{array}{l}\text { Model } 3 \\
\text { OR } 95 \% \mathrm{Cl}\end{array}$ & $\begin{array}{l}\text { Model } 4 \\
\text { OR } 95 \% \mathrm{Cl}\end{array}$ \\
\hline \multirow[t]{2}{*}{ Work-life balance } & WIPL $^{a}$ & $2.05^{* *}$ (1.46 to 2.88$)$ & $1.76^{* *}$ (1.23 to 2.51$)$ & $1.78^{* *}(1.22$ to 2.59$)$ & $1.92^{* *}(1.29$ to 2.87$)$ & $1.59^{*}(1.03$ to 2.44$)$ \\
\hline & PLIW ${ }^{a}$ & $3.35^{* *}$ (1.78 to 6.34$)$ & $2.44^{* *}(1.27$ to 4.68$)$ & $2.60^{* *}(1.33$ to 5.11$)$ & $3.38^{* *}(1.64$ to 6.96$)$ & $2.88^{* *}(1.31$ to 6.32$)$ \\
\hline \multirow[t]{9}{*}{ Employment } & Company & & & & & \\
\hline & Company 1 & 1 & & 1 & 1 & 1 \\
\hline & Company 2 & $2.36^{*}(1.12$ to 4.90$)$ & & $2.20(0.84$ to 5.74$)$ & $2.47(0.91$ to 6.71$)$ & 2.38 (0.83 to 6.83$)$ \\
\hline & Company 3 & 1.38 (0.64 to 2.97$)$ & & 1.30 (0.49 to 3.48$)$ & 1.46 (0.54 to 3.99$)$ & 1.27 (0.44 to 3.68) \\
\hline & Position at work & & & & & \\
\hline & Production & 1 & & 1 & 1 & 1 \\
\hline & Administration & 0.80 (0.44 to 1.47$)$ & & 0.95 (0.48 to 1.87$)$ & 0.71 (0.32 to 1.56$)$ & $0.66(0.28$ to 1.56$)$ \\
\hline & Manager & $0.83(0.38$ to 1.83$)$ & & $1.02(0.41$ to 2.50$)$ & $0.71(0.270$ to 1.87$)$ & 0.80 (0.29 to 2.23$)$ \\
\hline & $\begin{array}{l}\text { Experience of } \\
\text { leadership quality }\end{array}$ & $1.46^{*}(1.05$ to 2.04$)$ & & $1.58^{*}(1.10$ to 2.28$)$ & $1.65^{* *}(1.13$ to 2.40$)$ & $1.49 *(1.003$ to 2.21$)$ \\
\hline \multirow[t]{8}{*}{ Demographic } & Gender & & & & & \\
\hline & Male & 1 & & & 1 & 1 \\
\hline & Female & 0.86 (0.53 to 1.42$)$ & & & 0.72 (0.33 to 1.55$)$ & 0.68 (0.29 to 1.58$)$ \\
\hline & Age & $1.00(0.97$ to 1.03$)$ & & & 0.99 (0.96 to 1.02$)$ & $1.00(0.96$ to 1.03$)$ \\
\hline & Education level & & & & & \\
\hline & University & 1 & & & 1 & 1 \\
\hline & $\begin{array}{l}\text { Secondary school } \\
\text { or equal }\end{array}$ & $0.83(0.45$ to 1.54$)$ & & & $1.11(0.44$ to 2.77$)$ & $1.28(0.46$ to 3.53$)$ \\
\hline & Compulsory school & 1.51 (0.78 to 2.95) & & & $3.39^{*}(1.06$ to 10.82$)$ & $3.85^{*}(1.07$ to 13.86$)$ \\
\hline \multirow{2}{*}{$\begin{array}{l}\text { Baseline work ability } \\
\text { regarding mental } \\
\text { demands }\end{array}$} & Lower at $T_{0}$ & 1 & & & & 1 \\
\hline & Higher at $\mathrm{T}_{0}$ & $6.92^{* *}$ (3.74 to 12.78$)$ & & & & $5.55^{* *}(2.75$ to 11.20$)$ \\
\hline \multicolumn{2}{|l|}{ Nagelkerke R Square $\left(R^{2}\right)$} & & $16 \%$ & $21 \%$ & $26 \%$ & $38 \%$ \\
\hline \multicolumn{2}{|l|}{$\Delta \mathrm{R}^{2}$} & & & $5 \%$ & $5 \%$ & $12 \%$ \\
\hline
\end{tabular}

Odds ratio (OR), 95\% Cl: 95\% confidence interval of factors predicting higher work ability regarding mental demands. Work ability regarding mental demands was dichotomized into lower work ability $(=0)$ and higher

work ability $(=1){ }^{*} P \leq 0.05,{ }^{* *} P \leq 0.01{ }^{a}$ Work interference with personal life (WIPL) and personal life interference with work (PLIW), was both three item index scales, ranging from 1 to 5 . ' Experience with leadership quality was measured with an index, ranging from 1 to 6 . Model $1=P$ LIW+WIPL, Model $2=$ Model $1+$ company+position at work+experience of leadership quality, Model $3=$ Model $2+$ gender+age + education level, Model $4=$ Model $3+$ baseline work ability regarding mental demands

carried out in several ways, e.g. thru implementing concepts such as the "healthy workplace" concept [51]. In the concept of the health-promoting workplace it is stated that the individual also is responsible for his or her health behavior, and at the same time the individual's health is also affected by factors in the environment which are beyond the individual's control [52]. Interventions to promote health and work ability are therefore more likely to be effective if they are addressed both at individual and organizational level (e.g. environment).

In general, it is difficult to separate the work from the private life, thereby employers and supervisors needs to cooperate and share the responsibility to promote work ability resources [5]. Thru the use of e-technologies, much work have migrated into the homes and etechnologies have blurred the lines between work and home, and studies have showed inconsistent results regarding the relationship between work-home practices and WLB $[53,54]$. In times with a pandemic, such as the current COVID-19 (Coronavirus) pandemic, more people are expected to work from home [55], which also may have significance for WLB and difficulties to separate work from private life.

This study showed that WLB influence work ability outcomes over time. Further investigations are needed regarding the long-term associations obtained in this study to determine potential causality between WLB and work ability. Further investigations need to focus more in detail on different sources for work ability, exploring which factors might be the most effective to influence in order to increase employees' work ability. This study involved employees in the energy and water sector, nevertheless WLB is understood as general and probably predicts other employees work ability in a similar way. More research is needed to understand how WLB could be managed in different branches and contexts to 
promote long-term work ability, also in times when an increased proportion of work takes place from home, which may increase the risks for interference [55, 56]. However, data collection for this study was done in a branch and at a time when homework was less common.

\section{Strengths and limitations}

The strengths of this study include the longitudinal approach, which makes it possible to study longitudinal association between predictors and outcomes. The response rate was reasonable according to what is expected in questionnaire-based follow-up studies.

This study also has some limitations worth noting. The data on work ability were self-reported, and therefore some of the respondents may have underestimated or overestimated their rate of work ability. No data on non-respondents were collected. To limit the impact of possible selection bias the model was adjusted for demographic variables such as gender, age and educational level.

Even if a fair degree of variance in the outcome measures was explained (Nagelkerke R Square ranging from 35 to $38 \%$ ), there is still a lot of unexplained variance left in the outcome measures. This indicates that there are other factors, not assessed in the regression models that affect work ability among the employees. It can be discussed whether the directions of causality in the underlying assumption are appropriate. As this study is not randomized, potential confounders has not been distributed randomly between the groups, thus, differences in outcomes at the end of a study period cannot be attributed to the predictor factors with full certainty.

The healthy worker effect (HWE), is a commonly discussed form of selection bias in relation to occupational cohort studies [57, 58]. HWE occurs when improper choice of comparison groups is used in occupational studies. The main mechanisms behind the HWE in cohort studies are health-based selection of workers into employment, and/or health-based differential losses to follow-up (healthy worker survivor effect) [59, 60]. The risk for HWE in this study was lowered by the use of internal comparisons between employees [58], and by only using respondents from the baseline that were employed, and also answered the follow-up questionnaire. Another known bias is measurement reactivity or question-behavior effect, which are concepts linked to the broader 'Hawthorne effect' [61]. The question-behavior effect has been demonstrated for a variety of behaviors, and the theory states that it is a risk that research may stimulate new thinking and new behaviors on the phenomenon that the research focus on [62]. In this study, questionnaires were distributed to the employees, and some results from the baseline questionnaire were communicated back to the participating companies as feedback after T0. This feedback may have affected the companies and improved the outcomes, in general, at the follow-up. This may also have contributed to the general increase that occurs in the WAS scale during the study period.

\section{Conclusion}

Work-life balance factors predicted good/excellent overall work ability compared with lifetime best, in this twoyear cohort study. Lower levels of work interference with personal life predicted higher work ability regarding physical and mental demands, and lower levels of personal life interference with work predicted higher work ability regarding physical demands. This study suggests that better work-life balance may lead to higher work ability among employees in the energy and water sector.

\section{Abbreviations \\ HWE: Healthy worker effect; WLB: Work-life balance; OR: Odds ratio; PATH: Practices for the achievement of total health; PLIW: Personal life interference with work; SPSS: Statistical package for the social sciences; WAI: Work ability index; WAS: Work ability score; WIPL: Work interference with personal life}

\section{Acknowledgments}

We are grateful to all the respondents for sharing their views and to the participating companies how let the employees complete the questionnaires during working hours.

\section{Authors' contributions}

EB designed the study, undertook the statistical modeling and led the writing. PL was the principal investigator, designed the data collection, was responsible for participant recruitment, and administrated the research funding and IA designed and administered the data collection, contributed to data interpretation, and commented on successive drafts of the manuscript and the handling of data. ÅA contributed to data interpretation and drafting of the manuscript. All authors read and approved the final version of the manuscript.

\section{Funding}

The GodA-project was financed and supported by grants from the AFA Insurance Research Foundation and University of Gävle. The funders had no role in the design of the study, analysis, interpretation of data and in writing the manuscript. Open Access funding provided by Uppsala University.

\section{Availability of data and materials}

The datasets used and analysed during the current study are available from the corresponding author on reasonable request.

\section{Declarations}

Ethics approval and consent to participate

The study was approved by the regional Ethical Committee of Clinical Investigation in Uppsala (Dnr: 2012/537). Participation was voluntary and performed under written informed consent. The questionnaire was electronically distributed and consent was obtained by asking the participants to check a box stating "I have read the information and agree to participate in this study" before they could access to the questionnaire.

Consent for publication

Not Applicable.

Competing interests

The authors declare that they have no competing interests. 


\section{Author details}

'Department of Public Health and Caring Sciences, Uppsala University, Box 564, SE-751 22 Uppsala, Sweden. ${ }^{2}$ Department of Occupational Health Science and Psychology, University of Gävle, Gävle SE-801 76, Sweden.

\section{Received: 20 August 2020 Accepted: 8 June 2021} Published online: 24 June 2021

\section{References}

1. Ilmarinen J, Tuomi K, Eskelinen L, Nygard CH, Huuhtanen P, Klockars M. Summary and recommendations of a project involving cross-sectional and follow-up studies on the aging worker in Finnish municipal occupations (1981-1985). Scand J Work Environ Health. 1991;17(Suppl 1):135-41.

2. Fischer F, Borges F, Rotenberg L, Latorre M, Soares N, Santa Rosa P, et al. Work ability of health care shift workers: what matters? Chronobiol Int. 2006; 23(6):1165-79. https://doi.org/10.1080/07420520601065083.

3. Oakman J, Neupane S, Proper Kl, Kinsman N, Nygård C-H. Workplace interventions to improve work ability: A systematic review and metaanalysis of their effectiveness. Scand J Work Environ Health. 2018;23(2):13446.

4. Lederer V, Loisel P, Rivard M, Champagne F. Exploring the diversity of conceptualizations of work (dis)ability: a scoping review of published definitions. J Occup Rehabil. 2014;24(2):242-67. https://doi.org/10.1007/s1 0926-013-9459-4.

5. IImarinen J. Work ability--a comprehensive concept for occupational health research and prevention. Scand J Work Environ Health. 2009:35(1):1-5. https://doi.org/10.5271/sjweh.1304.

6. Tengland P-A. The concept of work ability. J Occup Rehabil. 2011;21(2):27585. https://doi.org/10.1007/s10926-010-9269-x.

7. Vanni K, Virtanen P, Luukkaala T, Nygard CH. Relationship between perceived work ability and productivity loss. Int J Occup Saf Ergon. 2012; 18(3):299-309. https://doi.org/10.1080/10803548.2012.11076946.

8. Kujala V, Tammelin T, Remes J, Vammavaara E, Ek E, Laitinen J. Work ability index of young employees and their sickness absence during the following year. Scand J Work Environ Health. 2006;32(1):75-84. https://doi.org/10.5271/ sjweh.979.

9. Reeuwijk KG, Robroek SJ, Niessen MA, Kraaijenhagen RA, Vergouwe Y, Burdorf A. The prognostic value of the work ability index for sickness absence among office workers. Plos One. 2015;10(5):e0126969. https://doi. org/10.1371/journal.pone.0126969.

10. Martinez MC, Fischer FM: Work Ability and Job Survival: Four-Year FollowUp. Int J Environ Res Public Health. 2019;16(17):3143.

11. Alavinia SM, de Boer AG, van Duivenbooden JC, Frings-Dresen MH, Burdorf A. Determinants of work ability and its predictive value for disability. Occup Med (Lond). 2009;59(1):32-7. https://doi.org/10.1093/occmed/kqn148.

12. von Bonsdorff MB, Seitsamo J, Ilmarinen J, Nygård C-H, von Bonsdorff ME, Rantanen T. Work ability in midlife as a predictor of mortality and disability in later life: a 28-year prospective follow-up study. CMAJ. 2011;183(4):E23542. https://doi.org/10.1503/cmaj.100713.

13. Serra C, Rodriguez MC, Delclos GL, Plana M, Gomez Lopez LI, Benavides FG. Criteria and methods used for the assessment of fitness for work: a systematic review. Occup Environ Med. 2007;64(5):304-12. https://doi.org/1 0.1136/oem.2006.029397.

14. Fadyl JK, McPherson KM, Schlüter PJ, Turner-Stokes L. Factors contributing to work-ability for injured workers: literature review and comparison with available measures. Disabil Rehabil. 2010;32(14):1173-83. https://doi.org/1 0.3109/09638281003653302.

15. Shaw WS, Robertson MM, Pransky G, McLellan RK. Employee perspectives on the role of supervisors to prevent workplace disability after injuries. J Occup Rehabil. 2003;13(3):129-42. https://doi.org/10.1023/A:1024997000505.

16. Emberland JS, Knardahl S. Contribution of psychological, social, and mechanical work exposures to low work ability: a prospective study. J Occup Environ Med. 2015;57(3):300-14. https://doi.org/10.1097/JOM. 0000000000000353

17. Olsen E, Bjaalid G, Mikkelsen A. Work climate and the mediating role of workplace bullying related to job performance, job satisfaction, and work ability: a study among hospital nurses. J Adv Nurs. 2017;73(11):2709-19. https://doi.org/10.1111/jan.13337.

18. Salmela-Aro K, Upadyaya K. Role of demands-resources in work engagement and burnout in different career stages. J Vocat Behav. 2018; 108:190-200. https://doi.org/10.1016/j.jvb.2018.08.002.
19. Crouter AC. Spillover from family to work - the neglected side of the work family interface. Hum Relat. 1984;37(6):425-41.

20. Greenhaus JH, Powell GN. When work and family are allies: a theory of work-family enrichment. Acad Manag Rev. 2006;31(1):72-92. https://doi. org/10.5465/amr.2006.19379625.

21. Barling J, Sorensen D. Work and family: in search of a relevant research agenda. New York: Wiley. 1997:157-69.

22. Poulose S, Sudarsan N. Work life balance: A conceptual review. Int J Adv Manag Econ. 2014;3(2):1-17.

23. Kalliath T, Brough P. Work-life balance: a review of the meaning of the balance construct. J Manag Organ. 2008;14(3):323-7. https://doi.org/10.51 72/jmo.837.14.3.323.

24. Marks SR, MacDermid SM. Multiple roles and the self: a theory of role balance. J Marriage Fam. 1996;58(2):417-32. https://doi.org/10.2307/353506.

25. Greenhaus JH, Collins KM, Shaw JD. The relation between work-family balance and quality of life. J Vocat Behav. 2003;63(3):510-31. https://doi. org/10.1016/S0001-8791(02)00042-8.

26. Gao Y, Shi J, Niu Q, Wang L. Work-family conflict and job satisfaction: emotional intelligence as a moderator. Stress Health. 2013;29(3):222-8. https://doi.org/10.1002/smi.2451.

27. Kahn RL, Wolfe DM, Quinn RP, Snoek JD, Rosenthal RA. Organizational stress: studies in role conflict and ambiguity; 1964.

28. Antai D, Oke A, Braithwaite P, Anthony DS. A 'Balanced' life: work-life balance and sickness absence in four Nordic countries. Int J Occup Environ Med. 2015;6(4):205-22. https://doi.org/10.15171/ijoem.2015.667.

29. Konrad AM, Mangel R. The impact of work-life programs on firm productivity. Strateg Manage J. 2000;21(12):1225-37. https://doi.org/10.1 002/1097-0266(200012)21:12<1225::AID-SMJ135>3.0.CO;2-3.

30. Haar JM, Russo M, Suñe A, Ollier-Malaterre A. Outcomes of work-life balance on job satisfaction, life satisfaction and mental health: a study across seven cultures. J Vocat Behav. 2014;85(3):361-73. https://doi.org/10.1016/j.jvb.2014.08.010.

31. van Solinge $H$, Henkens K. Living longer, working longer? The impact of subjective life expectancy on retirement intentions and behaviour. Eur J Pub Health. 2010;20(1):47-51. https://doi.org/10.1093/eurpub/ckp118.

32. K C P, Oakman J, Nygård C-H, Siukola A, Lumme-Sandt K, Nikander P, Neupane S: Intention to Retire in Employees over 50 Years. What is the Role of Work Ability and Work Life Satisfaction? Int J Environ Res Public Health. 2019, 16(14):2500.

33. Loeppke RR, Schill AL, Chosewood LC, Grosch JW, Allweiss P, Burton WN, et al. Advancing workplace health protection and promotion for an aging workforce. J Occup Environ Med. 2013;55(5):500-6. https://doi.org/10.1097/ JOM.0b013e31829613a4.

34. Boström M, Holmgren K, Sluiter JK, Hagberg M, Grimby-Ekman A. Experiences of work ability in young workers: an exploratory interview study. Int Arch Occup Environ Health. 2016;89(4):629-40. https://doi.org/10.1 007/s00420-015-1101-7.

35. Lindberg P, Anderzén I, Karlsson T, Strömberg A, Gustafsson S. The birth, rise and success (or fall?) of an intervention project : GodA - a project set up to test a model of the prerequisites for a healthy workplace. In: The 3rd International Wellbeing at Work conference, 26-28 May 2014, Copenhagen, Denmark; 2014

36. Grawitch MJ, Gottschalk M, Munz DC. The path to a healthy workplace: a critical review linking healthy workplace practices, employee well-being, and organizational improvements. Consult Psychol J. 2006;58(3):129-47. https://doi.org/10.1037/1065-9293.58.3.129.

37. Clarke MC, Koch LC, Hill EJ. The work-family Interface: differentiating balance and fit. Fam Consum Sci Res J. 2004;33(2):121-40. https://doi.org/10.1177/1 $077727 \times 04269610$.

38. Pichler F. Determinants of work-life balance: shortcomings in the contemporary measurement of WLB in large-scale surveys. Soc Indic Res. 2008;92(3):449.

39. Fisher GG, Bulger CA, Smith CS. Beyond work and family: a measure of work/nonwork interference and enhancement. J Occup Health Psychol. 2009;14(4):441-56. https://doi.org/10.1037/a0016737.

40. Yusuf S. A Comparative Study of Work-Life Balance and Job Satisfaction of the Employees Working in Business Process Outsourcing Sector. Sciences. 2018;10(2):87-93.

41. IImarinen J. The work ability index (WAI). Occup Med. 2007;57(2):160.

42. Ahlstrom L, Grimby-Ekman A, Hagberg M, Dellve L. The work ability index and single-item question: associations with sick leave, symptoms, and health--a prospective study of women on long-term sick leave. Scand J Work Environ Health. 2010;36(5):404-12. https://doi.org/10.5271/sjweh.2917. 
43. Lau B, Shiryaeva O, Ruud T, Victor M. What are they returning to? Psychosocial work environment as a predictor of returning to work among employees in treatment for common mental disorders: a prospective observational pre-post study. Plos One. 2019;14(4):e0215354. https://doi. org/10.1371/journal.pone.0215354.

44. Oellingrath IM, De Bortoli MM, Svendsen MV, Fell AKM. Lifestyle and work ability in a general working population in Norway: a cross-sectional study. BMJ Open. 2019;9(4):e026215. https://doi.org/10.1136/bmjopen-2018-026215.

45. Forsbrand MH, Turkiewicz A, Petersson IF, Sennehed CP, Stigmar K: Longterm effects on function, health-related quality of life and work ability after structured physiotherapy including a workplace intervention. A secondary analysis of a randomised controlled trial (WorkUp) in primary care for patients with neck and/or back pain. Scand J Prim Health Care 2020;38:1-9.

46. Dahl AA, Brennhovd B, Fosså SD, Axcrona K. A cross-sectional study of current work ability after radical prostatectomy. BMC Urol. 2020;20(1):9-9. https://doi.org/10.1186/s12894-020-0579-9.

47. Beauregard TA, Henry LC. Making the link between work-life balance practices and organizational performance. Hum Resour Manag Rev. 2009; 19(1):9-22. https://doi.org/10.1016/..hrmr.2008.09.001.

48. Neto M, Carvalho VS, Chambel MJ, Manuel S, Pereira Miguel J, de Fátima RM. Work-family conflict and employee well-being over time: the loss spiral effect. J Occup Environ Med. 2016;58(5):429-35. https://doi.org/10.1097/ JOM.0000000000000707.

49. Eaton SC. If you can use them: flexibility policies, organizational commitment, and perceived performance. Ind Relat. 2003;42(2):145-67.

50. Perry-Smith JE, Blum TC. Work-family human resource bundles and perceived organizational performance. Acad Manag J. 2000;43(6):1107-17.

51. Sauter SL. Organizational health : A new paradigm for occupational stress research at NIOSH. 産業精神保健. 1996;4:248-54.

52. Shain M, Kramer DM. Health promotion in the workplace: framing the concept; reviewing the evidence. Occup Environ Med. 2004;61 (7):643-585. https://doi.org/10.1136/oem.2004.013193.

53. Hill EJ, Ferris M, Märtinson V. Does it matter where you work? A comparison of how three work venues (traditional office, virtual office, and home office) influence aspects of work and personal/family life. J Vocat Behav. 2003;63(2): 220-41. https://doi.org/10.1016/50001-8791(03)00042-3.

54. Delanoeije J, Verbruggen M: The Use of Work-Home Practices and WorkHome Conflict: Examining the Role of Volition and Perceived Pressure in a Multi-Method Study. Front Psychol. 2019;10(2362):2362.

55. Burdorf A, Porru F, Rugulies R. The COVID-19 (Coronavirus) pandemic: consequences for occupational health. Scand J Work Environ Health. 2020; 46(3):229-30.

56. Arbetsmiljöverket: Gränslöst arbete: En forskarantologi om arbetsmiljöutmaningar i anknytning till ett gränslöst arbetsliv. In., vol. 2018:1: Arbetsmiljöverket; 2018.

57. McMichael AJ. Standardized mortality ratios and the "healthy worker effect": scratching beneath the surface. J Occup Med. 1976;18(3):165-8. https://doi. org/10.1097/00043764-197603000-00009.

58. Chowdhury R, Shah D, Payal AR. Healthy worker effect phenomenon: revisited with emphasis on statistical methods - a review. Indian J Occup Environ Med. 2017;21(1):2-8. https://doi.org/10.4103/ijoem.IJOEM_53_16.

59. Monson RR. Observations on the healthy worker effect. J Occup Med. 1986; 28(6):425-33. https://doi.org/10.1097/00043764-198606000-00009.

60. Pearce N, Checkoway H, Kriebel D. Bias in occupational epidemiology studies. Occup Environ Med. 2007;64(8):562-8. https://doi.org/10.1136/oem.2 006.026690

61. Miles LM, Elbourne D, Farmer A, Gulliford M, Locock L, McCambridge J, et al. Bias due to MEasurement reactions in trials to improve health (MERIT): protocol for research to develop MRC guidance. Trials. 2018;19(1):653. https://doi.org/10.1186/s13063-018-3017-5.

62. Spangenberg ER, Kareklas I, Devezer B, Sprott DE. A meta-analytic synthesis of the question-behavior effect. J Consum Psychol. 2016;26(3):441-58. https://doi.org/10.1016/j.jcps.2015.12.004.

\section{Publisher's Note}

Springer Nature remains neutral with regard to jurisdictional claims in published maps and institutional affiliations.

Ready to submit your research? Choose BMC and benefit from:

- fast, convenient online submission

- thorough peer review by experienced researchers in your field

- rapid publication on acceptance

- support for research data, including large and complex data types

- gold Open Access which fosters wider collaboration and increased citations

- maximum visibility for your research: over $100 \mathrm{M}$ website views per year

At BMC, research is always in progress.

Learn more biomedcentral.com/submissions 